\title{
42. REMARKS ON THE DETERMINATION OF THE PLIOCENE/PLEISTOCENE BOUNDARY IN THE MEDITERRANEAN
}

\author{
Germaine Bizon, Bureau d'Etudes Industrieles et de Coopération de l'Institut Français du Pétrole, \\ Rueil-Malmaison, France \\ and \\ Carla Müller, Geologisch-Paläontologisches Institut der Universität \\ Frankfurt am Main, Frankfurt am Main, Germany
}

\begin{abstract}
Differences exist between the western and eastern Mediterranean concerning the distribution and extinction of discoasters and the first occurrence of Globorotalia truncatulinoides. This led to an investigation of one suitable criterion for determining the position of the Plio/Pleistocene boundary. Investigations of Leg $42 \mathrm{~A}$ (Sites $371,372,374,376$, and 378) and Leg 13 (Sites 132 and 125) material show that the extinction of Cyclococcolithus macintyrei and Globigerinoides obliquus, which are virtually simultaneous, seem to provide the most useful biostratigraphic event with which to determine the Plio/Pleistocene boundary in the Mediterranean.
\end{abstract}

\section{INTRODUCTION}

Although there are many publications concerning the Plio/Pleistocene boundary, the problem of its identification has not been resolved. The extinction of Discoaster brouweri and the evolutionary appearance of Globorotalia truncatulinoides from Globorotalia tosaensis, and other criteria, have been regarded as characteristic of the boundary in deep-sea cores (Ericson et al., 1963; Riedel et al., 1963; Hays et al., 1969; Gartner 1969; Berggren et al., 1967). Attempts have been made to confirm these criteria in the type section of the Calabrian Stage at Santa Maria di Catanzaro and at Le Castella, the stratotype section for the Plio/ Pleistocene boundary; interpretations by different authors are contradictory (Gignoux, 1910, 1913; Banner and Blow, 1965; Blow, 1969; Hay and Boudreaux, 1968; Smith, 1969; Bayliss, 1969; Bandy and Wilcoxon, 1970; Takayama, 1970; Brolsma and Meulenkamp, 1973; Schmidt, 1973; Rio, 1974; Emiliani et al., 1961).

Hyalinea balthica, commonly used on-shore for the determination of the Plio/Pleistocene boundary in the Mediterranean, has not been found in deep-sea cores at or near this boundary. The use of this species to determine the base of the Pleistocene has been discussed by Bayliss (1969, 1975), Selli (1971), and Lamb and Beard (1972). The first occurrence of it in Indonesia (East Java) is in the early Pliocene (with Globorotalia margaritae) which means that this biostratigraphic event is not isochronous throughout the world.

According to Dondi and Papetti (1968), Colalongo (1968), and Cita et al. (1973), the first evolutionary appearance of Globorotalia truncatulinoides from Globorotalia tosaensis cannot be used in the Mediterra- nean because Globorotalia tosaensis is missing or rare in the late Pliocene whereas cold temperate microfaunas with Globorotalia inflata are generally represented. The first occurrence of Globorotalia truncatulinoides (without ancestors) may thus be controlled by ecological factors and, in the Mediterranean, cannot be used for precise determination of the Plio/Pleistocene boundary.

Because it is not possible, at this time, to give a comprehensive summary of the historical background of the Pliocene/Pleistocene boundary problem, only the results and interpretations of data from Leg $42 \mathrm{~A}$ and Leg 13 are presented here.

\section{RESULTS OF INVESTIGATIONS}

The following data concerning the determination of the Plio/Pleistocene boundary have been obtained from Sites 371, 372 (Leg 42A) and 132 (Leg 13) for the western Mediterranean, and from Sites 125 (Leg 13 ), and 374,376 , and 378 (Leg 42A) for the eastern Mediterranean (Figure 1).

\section{Western Mediterranean}

Site 371 (location: $37^{\circ} 55.88^{\prime} \mathrm{N}, 05^{\circ} 15.55^{\prime} \mathrm{E}$; water depth: $2792 \mathrm{~m}$ )

\section{Nannoplankton}

The stratigraphic interval of the Plio/Pleistocene boundary was incompletely cored at Site 371; three sections of Core 2 (199.5-209.5 m) were recovered, but between this core and Core $3(361-370 \mathrm{~m})$ a 154-meter sediment interval was not recovered.

The last Cyclococcolithus macintyrei was observed in Sample 2-3, 1-2 cm; it is not present in the following sample, 2-2, 133-134 cm, but occurs sporadically, 

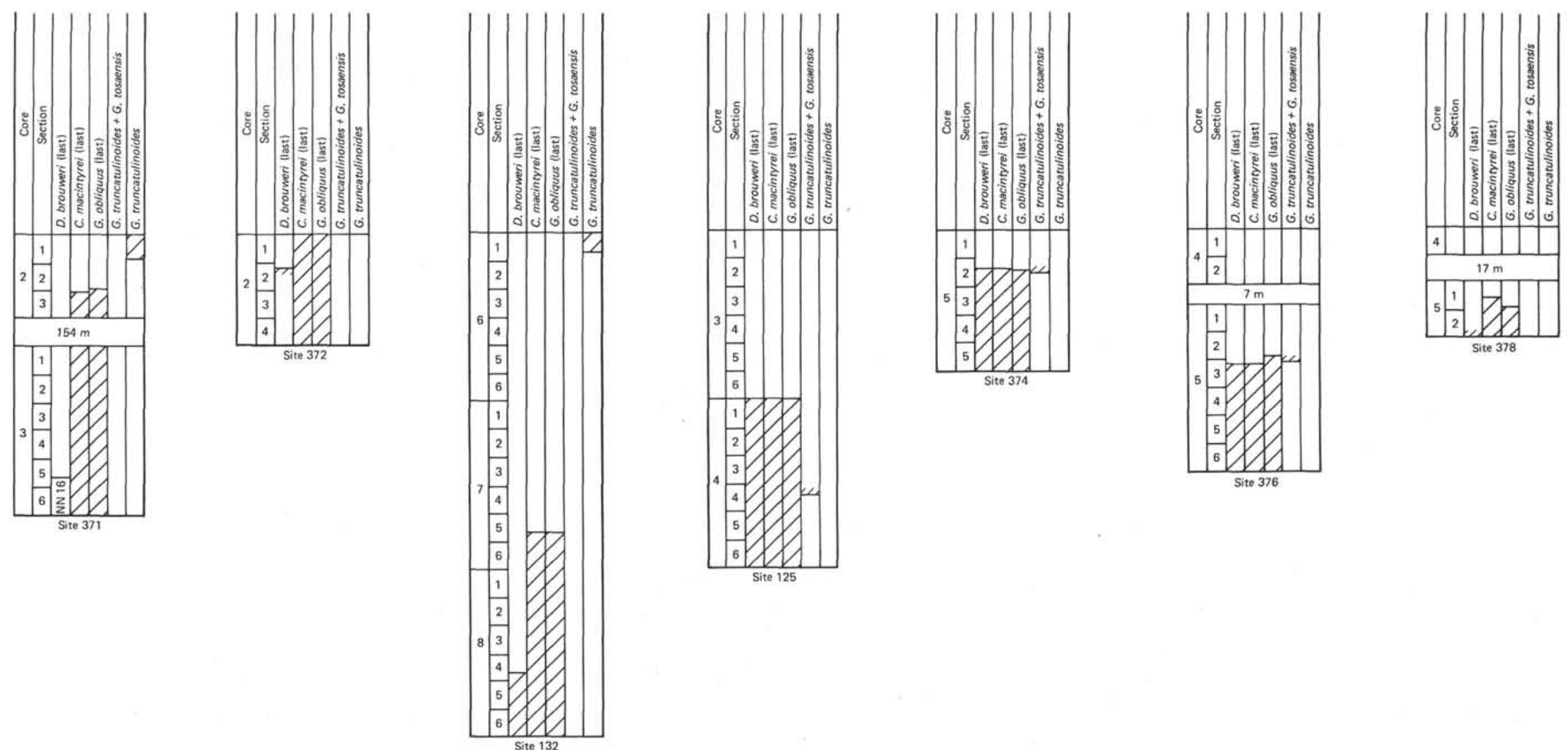

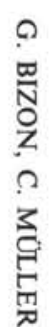

Site 371

Site 132

Figure 1. Distribution of the nannofossils, and foraminifers used for the determination of the Plio/Pleistocene boundary in the Mediterranean drill sites. 
together with other reworked species of the Neogene, in Sample 2-2, 110-111 cm. At the same level a distinct decrease of Coccolithus pelagicus, a cold water species, was observed. Discoasters are missing in Section 3 of Core 2 as well as in Sections 1 to 4 of Core 3. The last few discoasters, Discoaster brouweri, D. pentaradiatus, D. surculus, D. asymmetricus, were found in Sample 3-5, 100-101 cm, indicating the Discoaster surculus/ Discoaster pentaradiatus Zone (NN 16/NN 17).

On the basis of the last occurrence of Cyclococcolithus macintyrei the Plio/Pleistocene boundary is thus determined to be in Core 2 between Sections 2 and 3 .

A distinct horizon containing a large variety of Braarudosphaera bigelowi in the lowermost Pleistocene (NN 19), from Sample 2-2, 14-15 cm, to Sample 2-2, 133-134 cm, corresponds with the upper part of the same horizon at Site 132, Sample 7-4, 148-150 cm, to Sample 7-5, 148-150 cm which encompasses the lowermost Pleistocene/uppermost Pliocene. In Samples 7-5, $100-102 \mathrm{~cm}$, and 7-5, 148-150 cm, at Site 132, Braarudosphaera bigelowi is accompanied by abundant Cyclococcolithus macintyrei. The corresponding level is absent at Site 371 which may indicate a small hiatus in the latter profile, and which would include the uppermost part of the Pliocene.

\section{Foraminifers}

The last occurrence of Globigerinoides obliquus was observed in Sample 2-2, $140 \mathrm{~cm}$; it is common in Sample 2, CC, and Core 3, Sections 1 to 4. A few specimens were found in Sample 2-2, $33 \mathrm{~cm}$, but they are probably reworked. The first appearance of Globorotalia truncatulinoides occurs in Sample 2-1, $120 \mathrm{~cm}$; rare specimens found in Sample 2, CC are most likely downhole contamination. Globigerinoides trilobus is missing in Core 3, Section 1 to 4 while Globorotalia inflata is abundant in this interval.

\section{Site 372 (location: $40^{\circ} 01.86^{\prime} \mathrm{N}, 04^{\circ} 47.79^{\prime} \mathrm{E}$; water depth: $2699 \mathrm{~m}$ )}

\section{Nannoplankton}

The lower Pleistocene Pseudoemiliania lacunosa zone, NN 19, was recognized in Core 1 (112-121 m) and Cyclococcolithus macintyrei has its last occurrence in Sample 2-1, 130-136 cm. Between Sections 1 to 4 of Core 2 discoasters are absent, but in Sample 2-2, 27-29 $\mathrm{cm}$, Discoaster brouweri is common and in Sample 2-3, $41-43 \mathrm{~cm}$, it is rare. Sample 2-4, 76-77 cm, is within the Discoaster surculus/Discoaster pentaradiatus zone (NN 16/NN 17) and in Sample 2-4, 106-107 cm, discoasters are missing.

The Plio/Pleistocene boundary is estimated to be between Core 1 and Core 2 at Site 372 .

\section{Foraminifers}

Pleistocene sediments are present in Core 1, where Globorotalia truncatulinoides occurs in Sections 1 to 3 . Globigerinoides obliquus is common in Core 2; Globigerinoides trilobus is missing in the upper part of Core 2 Globorotalia inflata and Globigerina gr. bulloides are common.

\author{
Site 132 (location: $40^{\circ} 15.70^{\prime} \mathrm{N}, 11^{\circ} 26.47^{\prime} \mathrm{E}$; \\ water depth: $2835 \mathrm{~m}$ )
}

\section{Nannoplankton}

Samples from the continuously cored interval of the Plio-Pleistocene boundary were studied to compare the results with those obtained from Leg $42 \mathrm{~A}$ material. The upper part (Samples 7-4, 148-150 cm, to 7-5, 50$52 \mathrm{~cm}$ ) of the Braarudosphaera bigelowi horizon (Samples 7-4, 148-150 cm, to 7-5, 148-150 cm) corresponds with the B. bigelowi horizon encountered at Site 371 in the lowermost Pleistocene. The lower part of this horizon is distinguished by the presence of Cyclococcolithus macintyrei, the equivalent of which is missing at Site 371.

The last occurrence of Cyclococcolithus macintyrei was determined to be in Sample 7-5, 101-103 cm. In Sample 7-5, 50-52 cm, no specimens of $C$. macintyrei are present.

Discoasters are missing in the interval of Samples $7-5,101-103 \mathrm{~cm}$, to 8-4, 50-52 cm, whereas Cyclococcolithus macintyrei is abundant throughout. The last Discoaster brouweri and D. triradiatus occur in Sample $8-4,100-102 \mathrm{~cm}$, at the base of the Olduvai event (Cita et al. 1973). Both species are rare within the Discoaster brouweri Zone (NN 18) but are frequent in Sample 9-2, 100-102 cm. Discoasters are also rare in the uppermost part of the Discoaster surculus/Discoaster pentaradiatus Zone (NN 16/NN 17) determined in Core 10 Section 1; they are common downwards from Sample 10-5, $48-50 \mathrm{~cm}$.

Based on the last occurrence of Cyclococcolithus macintyrei the Plio/Pleistocene boundary is determined to lie between Sample 7-5, $51-53 \mathrm{~cm}$, and Sample 7-5, 101-103 cm, about 8 meters higher in the section than Stradner (1973) and Bukry (1973), using the extinction of discoasters, recognize it to be.

\section{Foraminifers}

Globorotalia truncatulinoides is common only in Sample 6-1, 0-2 cm. In Sample 6-3, 100-102 cm, and Sample 6-6, 100-102 cm, few thick-walled specimens were found. The last Globigerinoides obliquus was determined in Sample 7-5, 100-102 cm.

G. trilobus, G. sacculifer and G. quadrilobatus occur sporadically in this profile (see also Cita et al., 1973), but are missing or are extremely rare from Sample 7-5, $100-102 \mathrm{~cm}$, to Sample 8-2, $48-50 \mathrm{~cm}$, where Globorotalia inflata and Globigerina bulloides, are common in all samples.

\section{Eastern Mediterranean}

\section{Site 125 (location: $34^{\circ} 37.49^{\prime} \mathrm{N}, 20^{\circ} 25.76^{\prime} \mathrm{E}$; water depth: $2782 \mathrm{~m}$ )}

\section{Nannoplankton}

The last occurrence of Cyclococcolithus macintyrei was observed in Sample 4-1, 2-4 cm, together with the sporadic occurrence of Discoaster brouweri and $D$. triradiatus. They are more frequent in Sample 4-1, 102-104 cm, and become common from Sample 4-1, 
$147-149 \mathrm{~cm}$. According to the paleomagnetic results of this profile (Cita et al., 1973) the extinction of discoasters lies in the uppermost part or even slightly above the Olduvai event (the top is not determined at Site 125). Discoasters in general are common in the upper Pliocene sediments of Site 125 but there are short intervals where they are rare or absent, i.e., Core 4, lower part of Section 4 to the upper part of Section 6.

The Plio/Pleistocene boundary is herewith placed between Sample 3-6, 141-143 cm, and Sample 4-1, 2-4 $\mathrm{cm}$, about 1 meter above the boundary determined by Stradner (1973) and Bukry (1973).

\section{Foraminifers}

First occurrence of Globorotalia truncatulinoides together with Globorotalia tosaensis was determined in Sample 4-4, 48-50 cm, below the last Discoaster brouweri. This is in accordance with the results of Cita et al. (1973). Globigerinoides obliquus is not present above Sample 4-1, 2-4 cm; it is common in Sections 1 and 2; and rare in Sections 3 to 6 of this core. $G$. trilobus and G. sacculifer are common throughout the profile, but they are missing or are rare from Sample 4-4, 145-147 cm, to Sample 4-5, 148-150 cm. Globorotalia inflata was not found in the upper Pliocene at Site 125 thus the uppermost zone of the Pliocene (Globorotalia inflata Zone) cannot be determined.

\section{Site 374: (location: $35^{\circ} 50.87^{\prime} \mathrm{N}, 18^{\circ} 11.78^{\prime} \mathrm{E}$, water depth: $4078 \mathrm{~m}$ )}

\section{Nannoplankton}

The Pseudoemiliania lacunosa Zone (NN 19) of the Pleistocene was determined from Sample 5-1, 147-148 $\mathrm{cm}$, to Sample $5-2,42-43 \mathrm{~cm}$, this interval is rich in reworked species of the Neogene. The Plio/Pleistocene boundary is determined between Sample 5-2, 42-43 $\mathrm{cm}$, and Sample 5-2, 52-53 cm, the latter containing abundant Cyclococcolithus macintyrei and discoasters. Reworked species are frequent in this sample. Discoaster brouweri and D. triradiatus typical for the Discoaster brouweri Zone (NN 18) are abundant in Samples 5-2, 72-73 cm, and 5-2, 148-149 cm. Discoaster pentaradiatus and Discoaster surculus were observed only sporadically in these samples together with other Miocene discoasters, which suggests that they are probably reworked.

A small hiatus including the lowermost part of the Pleistocene and the uppermost part of the Discoaster brouweri Zone (NN 18) is suspected. The abundance of discoasters and scyphospheres indicate warmer water in this interval.

\section{Foraminifers}

The first appearance of Globorotalia truncatulinoides is in Sample 5-2, 75-77 cm, where it is associated with G. tosaensis and Sphaeroidinella dehiscens. The last occurrence of Globigerinoides obliquus is in Sample 5-2, $64-66 \mathrm{~cm}$. Globorotalia inflata is missing in the upper Pliocene.

\author{
Site 376: (location: $34^{\circ} 52.32^{\prime} \mathrm{N}, 31^{\circ} 48.45^{\prime} \mathrm{E}$, \\ water depth: $2101 \mathrm{~m}$ )
}

\section{Nannoplankton}

The last occurrence of Discoaster brouweri and Cyclococcolithus macintyrei occurs in Sample 5-3, 20$21 \mathrm{~cm}$; in Sample 5-3,100-101 cm, D. triradiatus is present. The Plio/Pleistocene boundary lies between Sample 5-2, 121-122 cm, and Sample 5-3, 20-21 cm.

The abundance of large Gephyrocapsa oceanica in the lowermost part of the Pleistocene at Site 376 suggests that the lowermost part of the Pseudoemiliania lacunosa Zone (NN 19) and perhaps the uppermost part of the Discoaster brouweri Zone (NN 18) is missing. Indications of contemporaneous tectonic events are given by the large amount of reworked Neogene nannoplankton in the sediments at this interval. They are missing in the extremely reduced upper Pliocene section. Discoasters are abundant through the Pliocene.

\section{Foraminifers}

The earliest appearance of Globorotalia truncatulinoides occurs together with G. tosaensis in Sample 5-3, $7-9 \mathrm{~cm}$. The last occurrence of Globigerinoides obliquus is in Sample 5-2, 130-133 cm, where it is rare and may be reworked. This species is more abundant in Sample $5-3,44-46 \mathrm{~cm}$. G. inflata is present only in the Quaternary sediments.

\section{Site 378: (location: $35^{\circ} 56.67^{\prime} \mathrm{N}, 25^{\circ} 06.97^{\prime} \mathrm{E}$, water depth: $1855 \mathrm{~m}$ )}

\section{Nannoplankton}

The Pleistocene Pseudoemiliania lacunosa Zone, NN 19 was determined to occur in Core 1 to Sample 4, CC. In Sample 4, CC, Cyclococcolithus macintyrei is present together with many reworked Neogene species. The Braarudosphaera bigelowi horizon was found in Sample 3-3, 100-111 cm, corresponding in its stratigraphic position with those described from Sites 371, 132 , and 130.

The Plio/Pleistocene boundary is located between Core 4 and Core 5. The last occurrence of Cyclococcolithus macintyrei lies in Sample 5-1, 81-82 cm, but without accompanying discoasters. The last Discoaster brouweri was observed in Sample 5, CC. Discoasters are also missing in Section 1 of Core 6 and are rare in Section 2. D. brouweri is common in Section 3 of this core. Discoasters are also missing or are rare in the upper part of the Discoaster surculus/Discoaster pentaradiatus Zone (NN 16/NN 17) in Sections 1 and 2 of Core 7. They become frequent below Section 3 .

\section{Foraminifers}

Globorotalia truncatulinoides was not found in this profile. The last occurrence of Globigerinoides obliquus was recorded from Sample 5-1, $124 \mathrm{~cm}$, together with Globorotalia inflata and abundant Globigerina gr. bulloides. $G$. inflata is rare in the upper Pliocene. 
Globigerinoides trilobus and Globigerinoides sacculifer are missing or are rare in almost all samples investigated, from the interval of the Plio/Pleistocene boundary and also in the middle and upper Pliocene. $G$. sacculifer is common only in Sample 6-3, 120-122 cm.

\section{DISCUSSION}

Preliminary results of these investigations show that the abundance and extinction of discoasters are different in the western and eastern Mediterranean, probably caused by different water temperatures. Therefore, they are not always useful for a precise determination of the Plio/Pleistocene boundary. It is known that discoasters are rare or or missing in regions of lower water temperature and can have an earlier extinction in high latitudes (North Atlantic, Perch-Nielsen, 1972; Norwegian-Greenland Sea, Müller, in press; southern high latitudes, Edwards and Perch-Nielsen, 1975; Bering Sea and North Pacific, Worsley, 1973). Another factor that complicates the determination of the PlioPleistocene boundary and/or the boundary between the Discoaster brouweri Zone (NN 18) and Discoaster surculus/Discoaster pentaradiatus Zone (NN 16/NN 17 ) is the occasional large amount of reworked Neogene species in this interval (Sites 374 and 376). Discoasters are extremely rare in the upper Pliocene of the western Mediterranean and often their presence is restricted to only some layers (Sites 371, 372, and 132 ). They become frequent downward from the middle part of the Discoaster surculus/Discoaster pentaradiatus Zone (NN 16/NN 17). Scarcity of discoasters in the upper Pliocene of the western Mediterranean was also reported by Bukry (1973), Schmidt (1973), Rio (1974), and Barbieri and Rio (1974). The determination of the Plio/Pleistocene boundary on the basis of the extinction of $D$. brouweri is thus often uncertain. Because of this problem, the boundary is determined by the extinction of Cyclococcolithus macintyrei, a biostratigraphic event at or very close to the extinction of $D$. brouweri as known from other regions. Investigations of deep-sea cores from the equatorial Pacific (Hays et al., 1969) and the Atlantic (Berggren et al., 1967) as well as from the Mediterranean (Cita et al., 1973) show a range for the discoaster extinction from below or at the base of the Olduvai event to the top or slightly above this event. Using the highest reported extinction level this corresponds approximately with the extinction of $C$. macintyrei which occurs slightly above the Olduvai event (Gartner, 1973).

Detailed investigations of the profiles of Sites 132 and 125 by Cita et al. (1973) and the results of the above reported studies give an extinction of the last Discoaster brouweri at the base of the Olduvai event at Site 132 and near or immediately above the top of the Olduvai event for Site 125. The extinction of Cyclococcolithus macintyrei is determined in both profiles slightly above the top of the Olduvai event. Because $C$. macintyrei appears to be less controlled by ecologic factors, its stratigraphic value becomes more important in areas where discoasters are missing or occur only sporadically.

The interval between the last occurrence of Cyclococcolithus macintyrei and the last occurrence of Discoaster brouweri and D. triradiatus is more significant in the western Mediterranean (about $8 \mathrm{~m}$ at Site 132 and only about $1 \mathrm{~m}$ at Sites 125 and 374 ) even if different sedimentation rates are taken in account. Comparison with the results obtained by investigation of the foraminifers shows that Cyclococcolithus macintyrei and Globigerinoides obliquus disappear at the same time in both the western and eastern Mediterranean. The extinction of G. obliquus at the Plio/Pleistocene boundary is also described by Berggren and Amdurer (1973) and Brinskin and Berggren (1975) from the Atlantic. Saito (1975) records the disappearance of $G$. obliquus 2 meters above the Plio-Pleistocene boundary at Le Castella. This event in general is also used to determine the boundary in land-sections where Globorotalia truncatulinoides is rare or missing.

The uppermost limit of Globigerinoides obliquus seems to be a more useful biostratigraphic event to determine the Plio/Pleistocene boundary in the Mediterranean, since the first evolutionary appearance of Globorotalia truncatulinoides has not been observed in the western Mediterranean where this species is rare and occurs sporadically in Quaternary sediments. However, the first occurrence of $G$. truncatulinoides together with $G$. tosaensis occurs below the last Discoaster brouweri in the eastern Mediterranean (Site 125). This overlap is also reported by Stainforth et al. (1975) from other regions.

Globorotalia inflata, the index fossil for the uppermost zone of the Pliocene (the base of the Globorotalia inflata Zone) is defined by its first occurrence (Cati et al, 1968), and is common in the upper Pliocene of the western Mediterranean (Sites 371, 372, and 132) whereas it is rare or missing in the eastern Mediterranean (Sites 125, 374, 376, and 378), probably because of ecological factors. The species is thus not useful in all parts of the Mediterranean as index fossil in the uppermost Pliocene.

At Sites 125, 374, and 376 the Globorotalia inflata Zone was not determinable due to the absence of that species. However, because the uppermost Pliocene nannoplankton zone (Discoaster brouweri Zone, NN 18) was determined at Sites 125 and 378 , and at least the lower part of this zone at Sites 374 and 376, there appears to be no or, at the most only a small hiatus in the uppermost Pliocene. A relationship between the presence of discoasters and Globigerinoides trilobus and Globigerinoides sacculifer was observed in the western and eastern Mediterranean. Both species are rare or are missing in the upper Pliocene of the western Mediterranean. They are more frequent in horizons which have abundant discoasters. Both species are better represented in the eastern Mediterranean, where also discoasters and scyphospheres were more frequent in what were warmer waters of the upper Pliocene. 


\section{CONCLUSIONS}

1. The determination of the Plio/Pleistocene boundary using the extinction of Discoaster brouweri and the first occurrence of Globorotalia truncatulinoides is somewhat uncertain in the Mediterranean. Both species seem to be ecologically controlled.

2. Abundance and distribution of discoasters and Globorotalia inflata in the upper Pliocene are different in the western and eastern Mediterranean.

3. Scarcity or absence of Globorotalia inflata in the eastern Mediterranean suggests a hiatus, including the Globorotalia inflata Zone of the upper Pliocene; this is not confirmed by results of nannoplankton studies.

4. Cyclococcolithus macintyrei and Globigerinoides obliquus became extinct at the same time. Both species seem to be less dependent upon ecological factors. We propose the use of the extinction of these species for the determination of the Plio/Pleistocene boundary in the Mediterranean.

\section{ACKNOWLEDGMENTS}

We thank W. A. Berggren for critically reviewing the manuscript and making many helpful suggestions. Laboratories preparations were made by C. Barrés and D. Parron.

\section{REFERENCES}

Bandy, O. L. and Wilcoxon, J. A., 1970. The PliocenePleistocene boundary, Italy and California: Geol. Soc. Am. Bull., v. 81 , p. $2939-2948$.

Banner, F. T. and Blow, W. H., 1965. Progress in the planktonic foraminiferal biostratigraphy of the Neogene: Nature, v. 208, p. 1164-1166.

Barbieri, F. and Rio, D., 1974. Calcareous nannoplankton from the Piacenzian (late Pliocene) of western Emily: Ateneo Parmense, Acta Nat, v. 10, p. 29-42.

Bayliss, D. D., 1969. The distribution of Hyalinea balthica and Globorotalia truncatulinoides in the type Calabria: Lethaia, v. 2, p. 133-143.

1975. The stratigraphy of the type section for the Pliocene/Pleistocene boundary in Italy: Micropaleontology, Spec. Publ., v. 1, p. 31-40.

Berggren, W. A. and Amdurer, M., 1973. Late Paleogene (Oligocene) and Neogene planktonic foraminiferal biostratigraphy of the Atlantic Ocean (lat. $30^{\circ} \mathrm{N}$ to lat. $30^{\circ} \mathrm{S}$ ). Riv. Ital. Paleontol., v. 79, p. 337-392.

Berggren, W. A., Phillips, J. D., Bertels, A., and Wall, D., 1967. Late Pliocene/Pleistocene stratigraphy in deep-sea cores from the south-central North Atlantic: Nature, v. 216 , p. 253-254.

Blow, W. H., 1969. Late middle Eocene to Recent planktonic foraminiferal biostratigraphy: Plankt. Microfossils Proc., Geneva, 1967, v. 1, p. 199-422.

Briskin, M. and Berggren, W. A., 1975. Pleistocene stratigraphy and quantitative paleo-oceanography of tropical north Atlantic: Micropaleontology, Spec. Publ., v. 1, p. 167-198.

Brolsma, M. J. and Meulenkamp, J. E., 1973. Lithostratigraphy and sedimentary history of the Calabrian deposits at Santa Maria di Catanzaro: Newsl. Strat., v. 3, p. 1-24.

Bukry, D., 1973. Coccolith stratigraphy Leg 13, Deep Sea Drilling Project. In Ryan, W. B. F., Hsü, K. J., et al.,
Initial Reports of the Deep Sea Drilling Project, Volume 13, Washington (U.S. Government Printing Office), Part 2, p. $817-822$.

Cati, F., Colalongo, M. L., Crescenti, U., d'Onofrio, S., Follador, U., Pirini Raddrizzani, C., Pomesano Cherchi, A., Salvatorini, G., Sartoni, S., Premoli Silva, I., Wezel, C. F., Bertolino, V., Bizon, G., Bolli, H. M., Borsetti Cati, A. M., Dondi, L., Feinberg, H., Jenkins, D. G., Perconig, E., Sampo, M., and Sprovieri, R., 1968. Biostratigrafia del Neogene mediterraneo basata sui foraminiferi planctonici: Boll. Soc. Geol. I., v. 87, p. 491-503.

Cita, M. B., Chierici, M. A., Ciampo, G., Moncharmont Zei, M., d'Onofrio, S., Ryan, W. B. F., and Scorziello, R., 1973. The Quaternary record in the Ionian and Tyrrhenian Basins of the Mediterranean Sea: In Ryan, W. B. F., Hsü, K. J., et al., Initial Reports of the Deep Sea Drilling Project, Volume 13, Washington (U.S. Government Printing Office), Part 2, p. 1263-1339.

Colalongo, M. L., 1968. Cenozone a foraminiferi ed ostracodi nel Pliocene e basso Pleistocene della Serie del Santerno e dell Appennino romagnolo: Giorn. Geol., v. 35, p. 29-61.

Dondi, L. and Papetti, I., 1968. Biostratigraphy of Po Valley Pliocene: Giorn. Geol. v, 35, p. 63-98.

Edwards, A. R. and Perch-Nielsen, K., 1975. Calcareous nannofossils from the southern Southwest Pacific, Deep Sea Drilling Project, Leg 29. In Kennett, J. P., Houtz, R. E., et al., Initial Reports of the Deep Sea Drilling Project, Volume 29, Washington (U.S. Government Printing Office), p. 469-539.

Emiliani, C., Mayeda, T., and Selli, R., 1961. Paleotemperature analysis of the Plio-Pleistocene section at Le Castella, Calabria, south Italy: Geol. Soc. Am. Bull., v. 72, p. 679688.

Ericson, D. B., Ewing, M., and Wollin, G., 1963. PliocenePleistocene boundary in deep sea sediments: Science, v. 139 , p. 727-737.

Gartner, S. Jr., 1969. Correlation of Neogene planktonic foraminifer and calcareous nannofossil zones: Gulf Coast Assoc. Geol. Soc. Trans., v. 19, p. 585-599.

1973. Absolute chronology of the Late Neogene calcareous nannofossil succession in the Equatorial Pacific: Geol. Soc. Am., v. 84, p. 2021-2034.

Gignoux, M., 1910. Sur la classification du Pliocène et du Quaternaire dans l'Italie du Sud: Compt. Rend. Acad. Sci., Paris, v. 150, p. 841-844.

Gignoux, M., 1913. Les formations marines pliocènes et quaternaires de l'Italie du Sud et de la Sicile: Ann. Univ. Lyon, N.S., v. 36, p. xxiv-693.

Hay, W. W. and Boudreaux, J. E., 1968. Calcareous nannofossils in the Submarex core, Nicaragua Rise, Caribbean Sea, Le Castella, Calabria, and the age of the PlioPleistocene boundary: Giorn. Geol., v. 35, p. 143-152.

Hays, J. D., Saito, T., Opdyke, N. D., and Burckle, L. H., 1969. Pliocene-Pleistocene sediments of the equatorial Pacific: their paleomagnetic, biostratigraphic, and climatic record: Geol. Soc. Am. Bull., v. 80, p. 1481-1514.

Lamb, J. L. and Beard, J. H., 1972. Late Neogene planktonic foraminifer in the Caribbean, Gulf of Mexico, and Italian stratotypes: Kansas Univ. Paleontol. Contrib., v. 57, p. 1-67.

Müller, C., 1976. Tertiary and Quaternary calcareous nannoplankton in the Norwegian-Greenland Sea, DSDP, Leg 38: In Talwani, M., Udintsev, G., et al., Initial Reports of the Deep Sea Drilling Project, Volume 38, Washington (U.S. Government Printing Office), p. 823-842. 
Perch-Nielsen, K., 1972. Remarks on Late Cretaceous to Pleistocene coccoliths from the North Atlantic: In Laughton, A. S., Berggren, W. A., et al., Initial Reports of the Deep Sea Drilling Project, Volume 12, Washington, (U.S. Government Printing Office), p. 1003-1069.

Riedel, W. R., Parker, F. L., and Bramlette, M. N., 1963. Pliocene-Pleistocene boundary in deep sea sediments: Science, v. 140, p. 1238-1240.

Rio, D., 1974. Remarks on late Pliocene-early Pleistocene calcareous nannofossils stratigraphy in Italy: Ateneo Parmense, Acta Nat., v. 10, p. 409-449.

Saito, T., Burckle, L. H., Hays, J. D., 1975. Late Miocene to Pleistocene biostratigraphy of equatorial Pacific sediments: Micropaleontology, Spec. Publ., v. 1, p. 226-244.

Selli R., 1971. Calabrian. In Carloni, G. C., Marks, P., Rutsch R. F., and Selli, R. Stratotypes of Mediterranean Neogene Stages: Giorn. Geol., v. 37, p. 55-64.

Schmidt, R. R., 1973. A calcareous nannoplankton zonation for upper Miocene-Pliocene deposits from the southern Aegean area, with a comparison to Mediterranean stratotype localities: Koninkl. Ned. Akad. Wetenschap., ser. B, v. 76 , p. 287-310.
Smith, L. A., 1969. Pleistocene discoasters at the stratotype of the Calabrian Stage (Santa Maria di Cantanzaro) and at Le Castella, Italy: Trans. Gulf Coast Assoc. Geol. Soc., v. 19 , p. $579-583$.

Stainforth, R. M., Lamb, J. L., Luterbacher, H., Beard, J. H., and Jeffords, R. M., 1975. Cenozoic planktonic foraminiferal zonation and characteristics of index forms: Kansas Univ. Paleontol. Contrib., v. 62, p. 1-162.

Stradner, H., 1973. Catalogue of calcareous nannoplankton from sediments of Neogene age in the eastern North Atlantic and Mediterranean Sea. In Ryan, W. B. F., Hsü, K. J., et al., Initial Reports of the Deep Sea Drilling Project, Volume 13, Washington (U.S. Government Printing Office), Part 2, p. 1137-1199.

Takayama, T., 1970. The Pliocene-Pleistocene boundary in the Lamont Core V 21-98 and at Le Castella, South Italy: Marine Geol., v. 6, p. 70-77.

Worsley, T. R., 1973. Calcareous nannofossils: Leg 19 of the Deep Sea Drilling Project. In Creager, J. S., Scholl, D. W., et al., Initial Reports of the Deep Sea Drilling Project, Volume 19, Washington (U.S. Government Printing Office), p. 741-750. 